\title{
A Study of the Effect of DC Conditions on a 5.8 GHz Power Amplifier's S-Parameters
}

\author{
Bilge ŞENEL ${ }^{1 *} \quad$ Mesud KAHRIMMAN ${ }^{1}$
}

\begin{abstract}
This study investigates changes of S-parameters $\left(S_{21}, S_{11}, S_{22}, S_{12}\right)$ of a SBB5089Z power amplifier module in relation to changing DC conditions. Behaviour of those linear performance parameters $\left(\mathrm{S}_{21}, \mathrm{~S}_{11}, \mathrm{~S}_{22}, \mathrm{~S}_{12}\right)$ was examined graphically. S-parameters of SBB5089Z were analysed covering the $5.8 \mathrm{GHz}$ WiMAX frequency from $5.7 \mathrm{GHz}$ to $5.9 \mathrm{GHz}$ with $200 \mathrm{MHz}$ bandwidth. DC conditions were controlled using a microcontroller, an R/2R Digital Analogue Converter (DAC) ladder circuit and a voltage follower with LM324. The R/2R ladder circuit and voltage follower with LM324 have been integrated with the microcontroller. Also ACS712 current sensor and ADS1115 16-bit Analog Digital Convertor (ADC) are integrated to the microcontroller. PA's current was read with microcontroller.
\end{abstract}

Keywords: Power Amplifier, WiMAX, 5.8 GHz, DC conditions, microcontroller

\section{Besleme Koşullarının 5.8 GHz Güç Yükselteci S-Parametreleri Etkisi Üzerine Bir Çalışma}

ÖZET: $\mathrm{Bu}$ çalışma, değişen DC koşullara bağlı olarak SBB5089Z güç yükselteç modülü Sparametrelerindeki $\left(S_{21}, \quad S_{11}, \quad S_{22}, S_{12}\right)$ değişimleri araştırmaktadır. Doğrusal performans parametrelerinin $\left(S_{21}, S_{11}, S_{22}, S_{12}\right)$ davranışı grafiksel olarak incelenmiştir. SBB5089Z' nin $S$ parametreleri, 5.8 GHz WiMAX frekansını kapsayan, 5.7 GHz'den 5.9 GHz'e kadar 200MHz bant genişliği ile analiz edilmiştir. DC koşullar, bir mikrodenetleyici, bir R/2R sayısal analog dönüştürücü merdiven devresi ve LM324'lü bir gerilim izleyici kullanılarak kontrol edilmiştir. R/2R merdiven devresi ve LM324'lü gerilim izleyici devresi mikrodenetleyici ile entegre edilmiştir. Aynı zamanda, mikrodenetleyiciye ACS712 akım sensörü ve ADS1115 16-bit analog sayısal dönüştürücü de entegre edilmiştir. Güç yükselteci akımı mikrodenetleyici ile ölçülmüştür.

Anahtar Kelimeler: Güç Yükselteci, WiMAX, 5.8 GHz, DC koşullar, Mikrodenetleyici

\footnotetext{
${ }^{1}$ Bilge ŞENEL (Orcid ID: 0000-0003-3612-936X), Mesud KAHRİMAN (Orcid ID: 0000-0003-0731-0936), Süleyman Demirel University, Engineering Faculty, Electronics and Communication Engineering, 32260, Isparta, Turkey

*Sorumlu Yazar/Corresponding Author: Bilge ŞENEL, e-mail: bilgeturkel@sdu.edu.tr
} 


\section{INTRODUCTION}

Amplification of the signal is one of the most basic and important functions of a microwave amplifier circuit (Pozar, 2012). Radio frequency (RF) Power Amplifiers (PAs) are important elements of wireless communication systems and are expected to provide appropriate output power at a good gain value with high efficiency and linearity. The output power of RF PAs should be sufficient for real communication (Saad, 2006; Kaya et al., 2008). While efficiency in PAs is important in terms of battery life, the importance of linear performance for PAs can be summarized in three points:

- Modern wireless communication systems use wide bandwidths, and therefore efficient use of the spectrum is required. This increases the need for wide-band linear amplifiers for transceiver systems.

- Since many wireless communication standards use a non-constant envelope modulation method (with high PAPR values), signals must be amplified by highly linear amplifiers.

- Sinusoidal input power applied to the amplifiers used in wireless transmitter systems is transformed into heat or high intermodulation (IM) outputs, outside of the amplifier's linear operating range (in the regions above the $1 \mathrm{~dB}$ gain compression point) (Pedro, 2003).

Due to the reasons mentioned above, high linearity amplifier design has become an important research topic in recent years. Linearity needs to be achieved within the rapidly developing and growing mobile device market with minimum circuit complexity, power consumption and cost (Brinkhoff, 2003).

In practice, PAs are driven with modulated RF signals varying in amplitude over time, and the amplitude of these signals is increasing or decreasing according to various conditions. Due to the high PAPR value of the modulated signal, the PAs to be used in those systems should be operated in highly linear regions with high power back-off values. On the other hand, operating the amplifier in the back-off region causes a drop in its efficiency. This poses a great challenge to PA designers, as the design of PAs has to meet the linearity requirements but still have highly efficient performance (Gecan et al., 2017; Tripathi et al., 2017). Gain, reflection coefficient, and linearity parameters of the PA get worse at high levels of the RF input signal. Therefore, for linear performance of a PA, it is preferred to operate in the back-off region. However, in the back-off region the efficiency of PAs gets worse (Lee, 2010). There is a trade-off between linearity and efficiency according to changing RF input power levels (Senel et al., 2017).

The deterioration of PA's performance parameters caused by RF input power can be improved by changing DC conditions (Cripps, 2002; Wong et al., 2012). There are many studies in literature on this subject. Dynamic gate biasing (Gecan et al., 2016), dynamic biasing (Lee et al., 2017; Chen et al., 2016), adaptive biasing (Harzheim, 2016; Cohen et al., 2013; Akbarpour, 2017), and envelope tracking (Auer et al., 2017; Olavsbråten and Gecan, 2017) are some of the methods of changing DC conditions depending on the RF input power signal. In dynamic biasing, dynamic gate biasing and adaptive biasing DC conditions change according to the power of the RF input signal (Tafuri, 2013), whereas in envelope tracking method DC conditions change according to the envelope of the RF input signal (Jing and Bakkaloğlu, 2017).

Detailed technical literature review has shown that DC conditions have a significant influence on PA's performance parameters. In the literature especially changing of nonlinear performance parameters of PA like output power, according to DC conditions have been investigated. In this study, we investigate how the linear gain $\left(S_{21}\right)$, input and output reflection 
coefficient $\left(\mathrm{S}_{11} \& \mathrm{~S}_{22}\right)$ and back transmission coefficient $\left(S_{12}\right)$ parameters of a SBB5089Z power amplifier module change with changing DC conditions from $5.7 \mathrm{GHz}$ to $5.9 \mathrm{GHz}$, with $200 \mathrm{MHz}$ bandwidths covering $5.8 \mathrm{GHz}$ WiMAX frequency. In this study firstly, we chose proper a commercial power amplifier module. As mentioned earlier it is SBB5089Z operating at $5.8 \mathrm{GHz}$ frequency and $5 \mathrm{~V}$ nominal $\mathrm{V}_{\mathrm{DC}}$. We began with measurement S-parameters of PA module whether PA module operates or not at $5.8 \mathrm{GHz}$ frequency. After verifying that PA module operates at $5.8 \mathrm{GHz}$ frequency with $200 \mathrm{MHz}$ bandwidth, we changed DC conditions $\left(\mathrm{V}_{\mathrm{D}}\right)$ of $\mathrm{PA}$ module from $0 \mathrm{~V}$ to $5 \mathrm{~V}$ and investigated how varied $\mathrm{S}$-parameters of PA.

\section{MATERIAL AND METHODS}

In this study we have used a $50 \mathrm{MHz}-6 \mathrm{GHz}$ broadband InGaP HBT MMIC SBB5089Z power amplifier module. Measured S-parameters $\left(\mathrm{S}_{21}, \mathrm{~S}_{11}, \mathrm{~S}_{22}, \mathrm{~S}_{12}\right)$ of the SBB5089Z module, from $5.7 \mathrm{GHz}$ to $5.9 \mathrm{GHz}$, are shown in Figure 1 . In measurements, the following equipment was used: a $6 \mathrm{GHz}$ Rohde\&Schwarz FSH6 spectrum analyzer, a DC power supply, and a broadband micro strip directional coupler - for dividing and monitoring the power levels. DC conditions were adjusted at $\mathrm{V}_{\mathrm{D}}=5 \mathrm{~V}$ and $\mathrm{I}_{\mathrm{D}}=69 \mathrm{~mA}$.

$\mathrm{S}$-parameters and DC power consumption are summarized in Table 1.

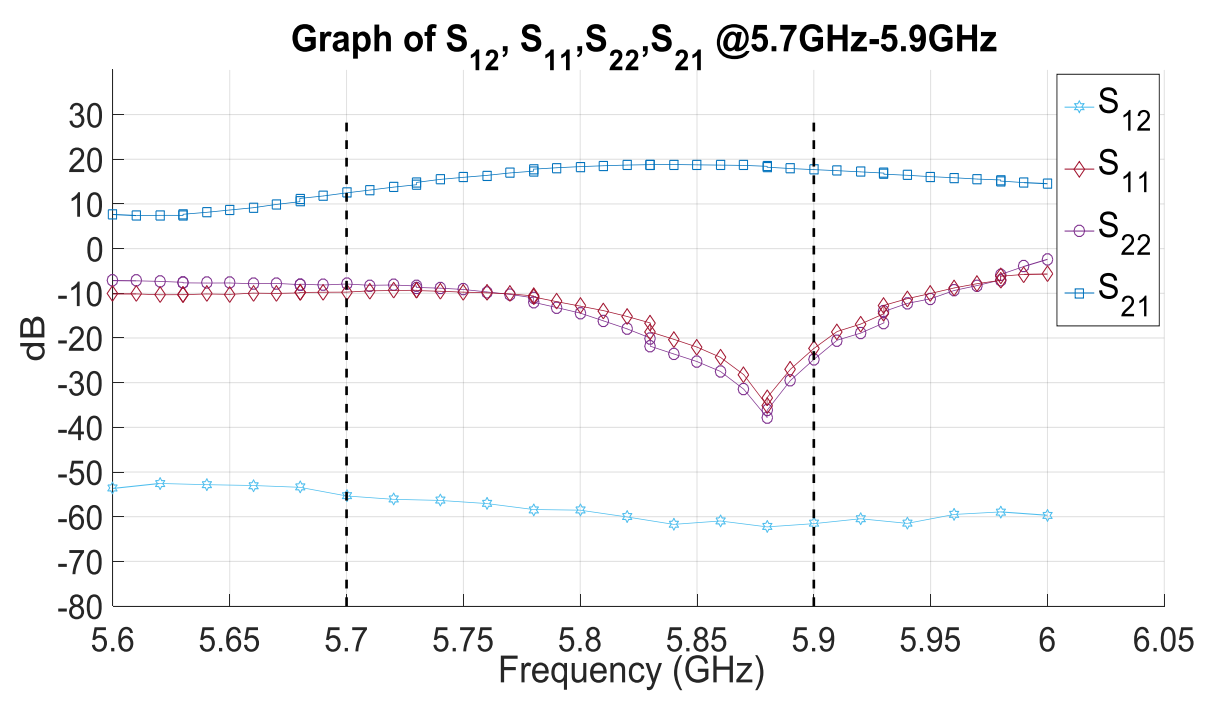

Figure 1. Measured s-parameters of SBB5089Z

Table 1. Performance parameters of SBB5089Z@5.8GHz

\begin{tabular}{|l|c|}
\hline Performance Parameters & Value \\
\hline$S_{21}(d B)$ & 18.35 \\
\hline$S_{11}(d B)$ & -14.43 \\
\hline$S_{22}(d B)$ & -12.87 \\
\hline$S_{12}(d B)$ & -58.54 \\
\hline$P_{\text {diss }}($ Watt $)\left(V_{D} * I_{D}\right)$ & 0.3725 \\
\hline
\end{tabular}

According to measurement results presented in Table 1, SBB5089Z has $\mathrm{S}_{21}>10 \mathrm{~dB}$, $S_{11} \& S_{22}<-10 \mathrm{~dB}$, and $S_{12}<-20 \mathrm{~dB}$, so they are sufficient for this work and meet the requirements. 


\section{Methodology of Changing the DC Voltages}

In the system designed in the study, the DC voltage values $\left(V_{D}\right)$ applied to the $P A$ are automatically changed with the microcontroller in 5 second periods. Thus, PA is automatically biased with $V_{D}$ voltage. The ACS712 current sensor and ADS 1115 16-bit Analog Digital Convertor (ADC) are integrated to the microcontroller. PA's current is also automatically read by the microcontroller with current sensor and ADC. S-parameters of PA were measured by the Rohde \& Schwarz FSH6 spectrum analyzer. Since the spectrum analyzer connected to the output of the PA is not suitable to be triggered by the microcontroller, the values that the spectrum analyzer reads are recorded in the .CSV file by the spectrum analyzer every 5

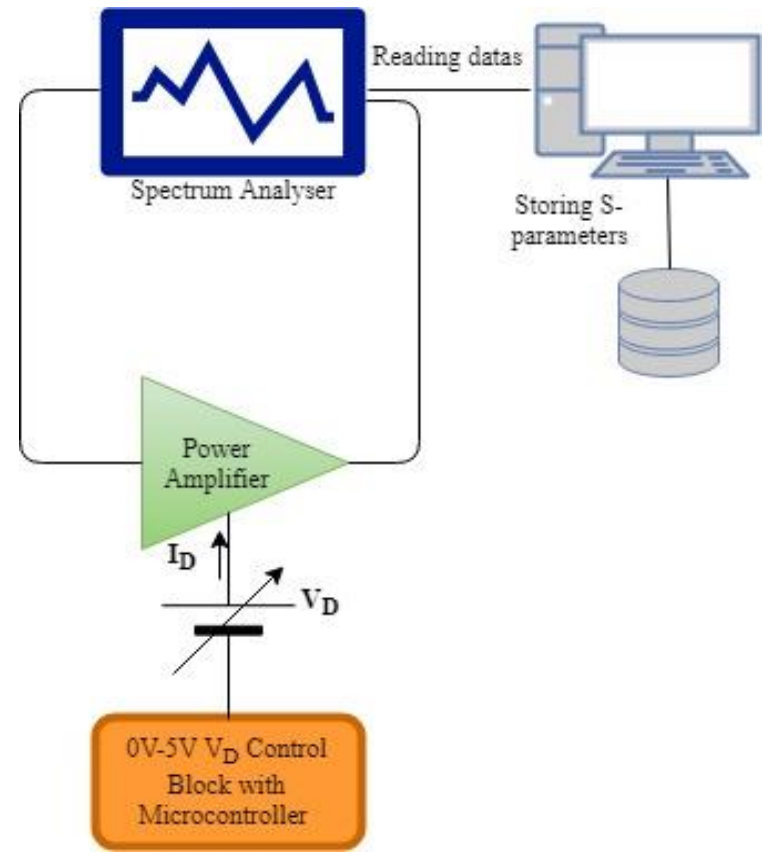

Figure 2. Block diagram of S-parameter measurement set up

\section{Biasing Control Unit with Microcontroller}

In this study, a microcontroller was used to change DC conditions of the SBB5089Z. Microcontroller's digital output pins were seconds synchronously with the microcontroller. After examining the S-parameters of the SBB5089Z PA module, the DC requirements of the SBB5089Z were changed from $0 \mathrm{~V}$ to $5 \mathrm{~V}$ in approximately $75 \mathrm{mV}$ steps (with 6-bit resolution, so $2^{6}=64$ steps) using the microcontroller. Because the maximum supply voltage $\left(V_{\mathrm{D}}\right)$ of SBB5089Z is $5.5 \mathrm{~V}$, in order not to burn out the PA module, DC voltage was changed only up to $5 \mathrm{~V}$. It has been studied graphically in detail how varying the DC conditions changes the linear performance parameters $\left(S_{21}, S_{11}, S_{22}, S_{12}\right)$ of the SBB5089Z. Block diagram of S-parameter measurement set up is shown in Figure 2, as well as microcontroller program flow chart is shown in Figure 3.

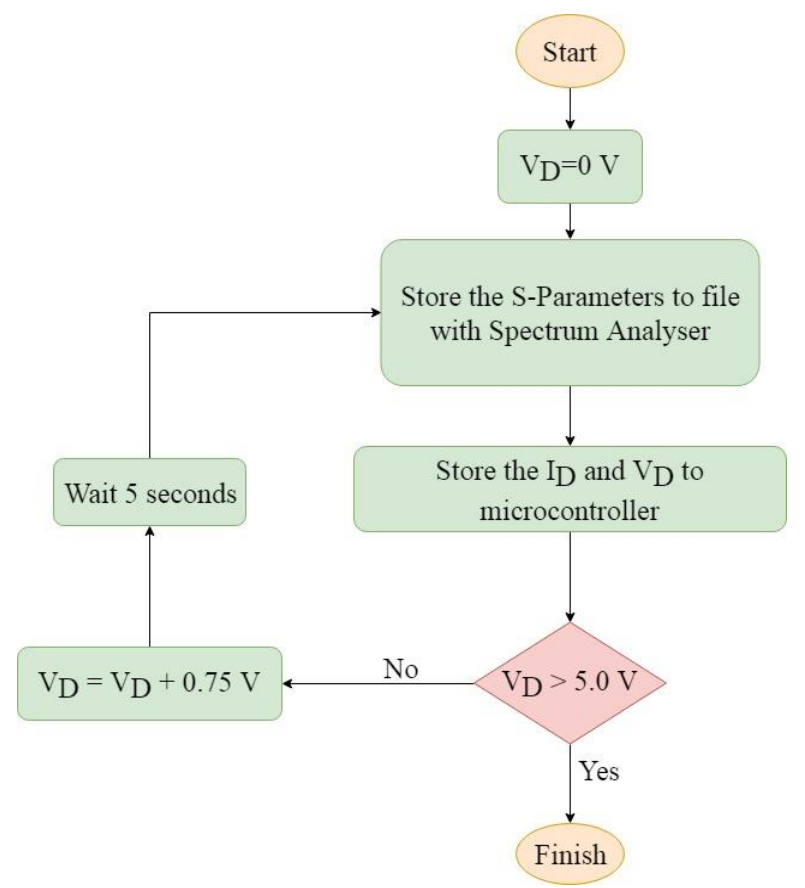

Figure 3. Microcontroller program flow chart

integrated to an $\mathrm{R} / 2 \mathrm{R}$ DAC ladder circuit to obtain more stable $\mathrm{V}_{\mathrm{D}}$. The LM324 voltage follower circuit was used after the $R / 2 R$ circuit and the SBB5089Z was driven by that LM324 voltage follower circuit. As well as a current sensor named ACS712 and a 16 bit ADS1115 
analog digital convertor are used to read current drawn by PA. The block diagram and implementation of the DC biasing control unit are shown in Figure 4 and 5, respectively.

Measurement set up is shown in Figure 6.

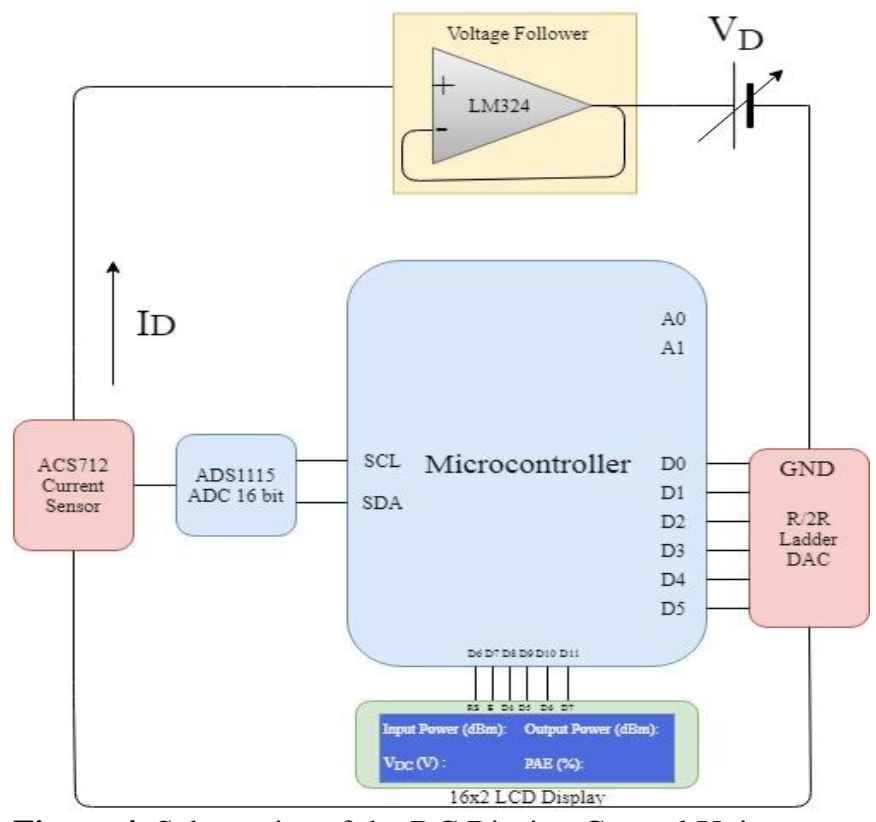

Figure 4. Schematics of the DC Biasing Control Unit

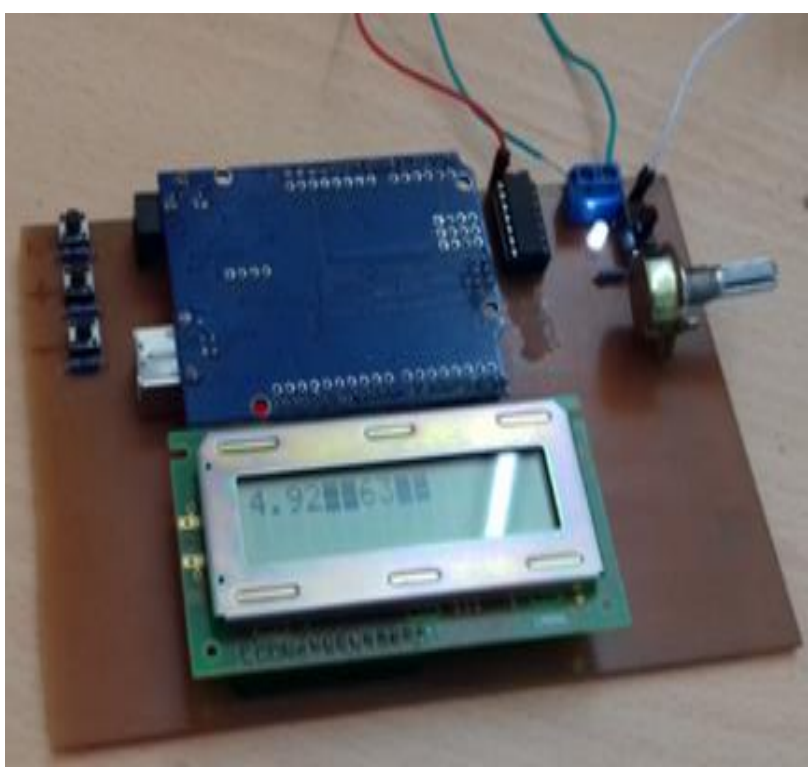

Figure 5. Implementation of the DC biasing control unit

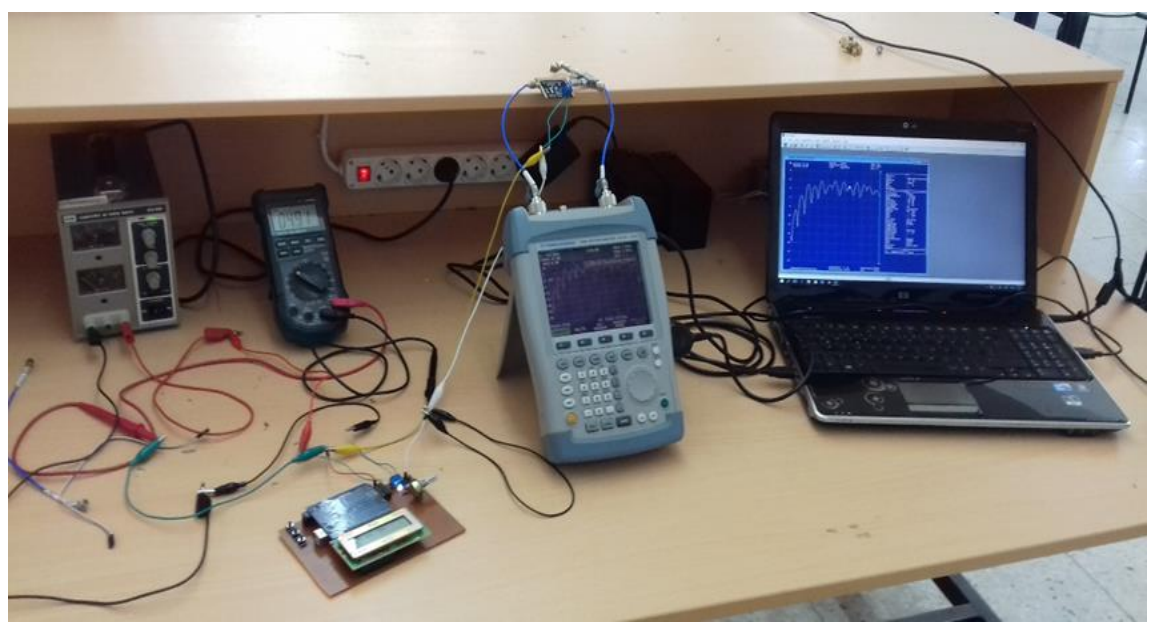

Figure 6. Measurement set up

\section{RESULTS AND DISCUSSION}

\section{Changing S-Parameters with Modified DC Conditions}

Figures 7 displays three-dimensional graphs of the $\mathrm{S}_{21}, \mathrm{~S}_{11}, \mathrm{~S}_{22}$, and $\mathrm{S}_{12}$ parameters, respectively, in relation to $\mathrm{V}_{\mathrm{D}}$, which is increasing in $75 \mathrm{mV}$ steps from $0 \mathrm{~V}$ to $5 \mathrm{~V}$, for a $200 \mathrm{MHz}$ bandwidth from $5.7 \mathrm{GHz}$ to $5.9 \mathrm{GHz}$, covering the $5.8 \mathrm{GHz}$ WiMAX band.
The increase/decrease of performance parameters of the SBB5089Z at $5.8 \mathrm{GHz}$, while DC conditions of the PA module were changed from $\mathrm{V}_{\mathrm{D}}=3.095 \mathrm{~V}$ to $5 \mathrm{~V}$, is summarized in Table 2. The minimum value of approximately $3 \mathrm{~V}$ was chosen for $V_{D}$, because $S_{11}$ and $S_{22}$ get much worse when $\mathrm{V}_{\mathrm{D}}$ drops below $3 \mathrm{~V}$. 


\section{D Graph of $\mathrm{S}_{21} @ 5.7 \mathrm{GHz}-5.9 \mathrm{GHz}$}

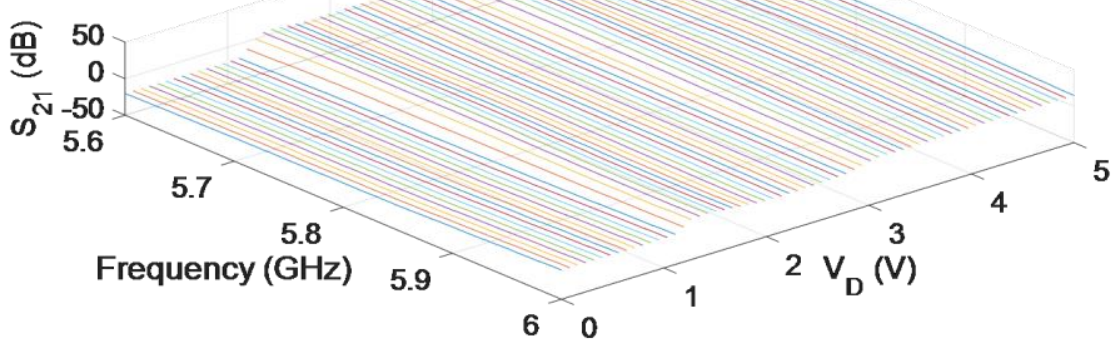

(a)

3D Graphs of $\mathrm{S}_{11} @ 5.7 \mathrm{GHz}-5.9 \mathrm{GHz}$

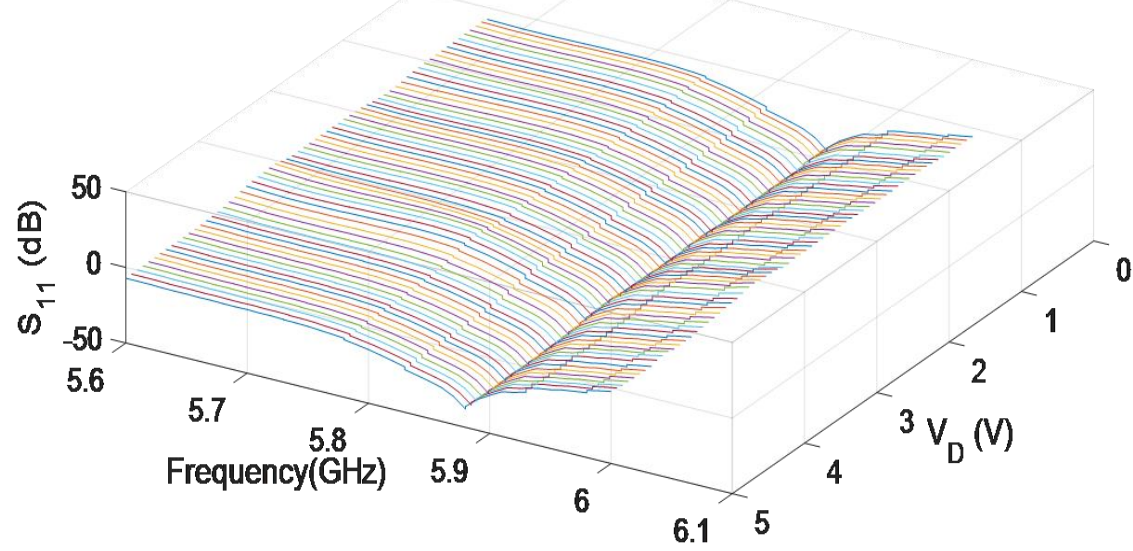

(b)

\section{D Graph of $\mathrm{S}_{22} 5.7 \mathrm{GHz}-5.9 \mathrm{GHz}$}

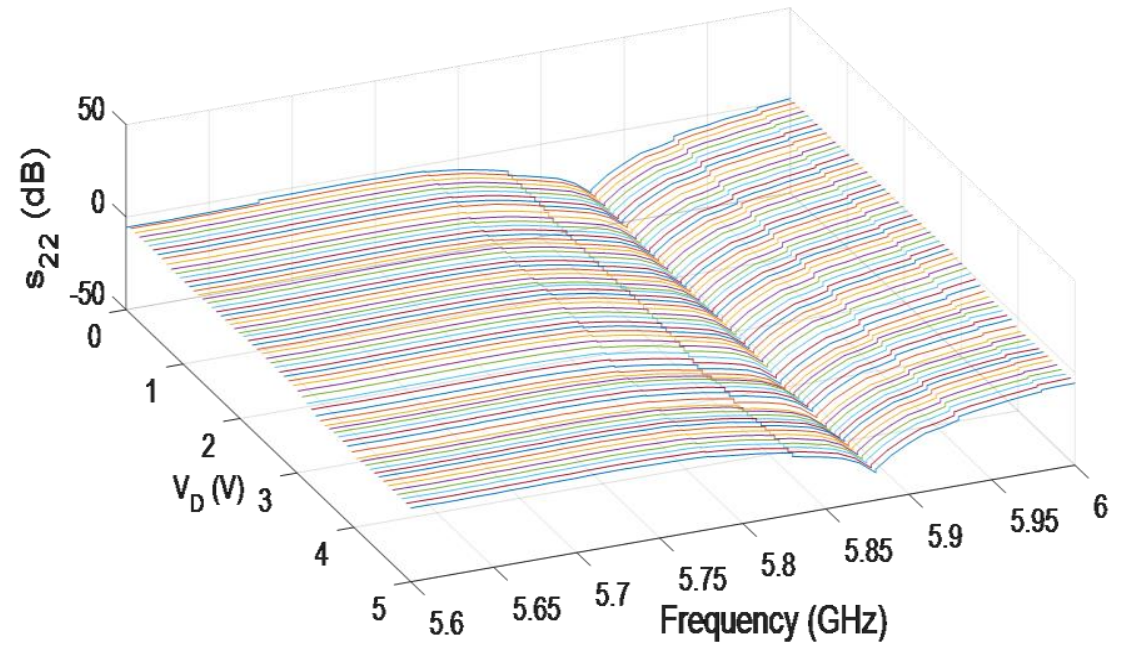

(c) 


\section{D Graph of $\mathrm{S}_{12} @ 5.7 \mathrm{GHz}-5.9 \mathrm{GHz} \mathrm{S}_{12}$}

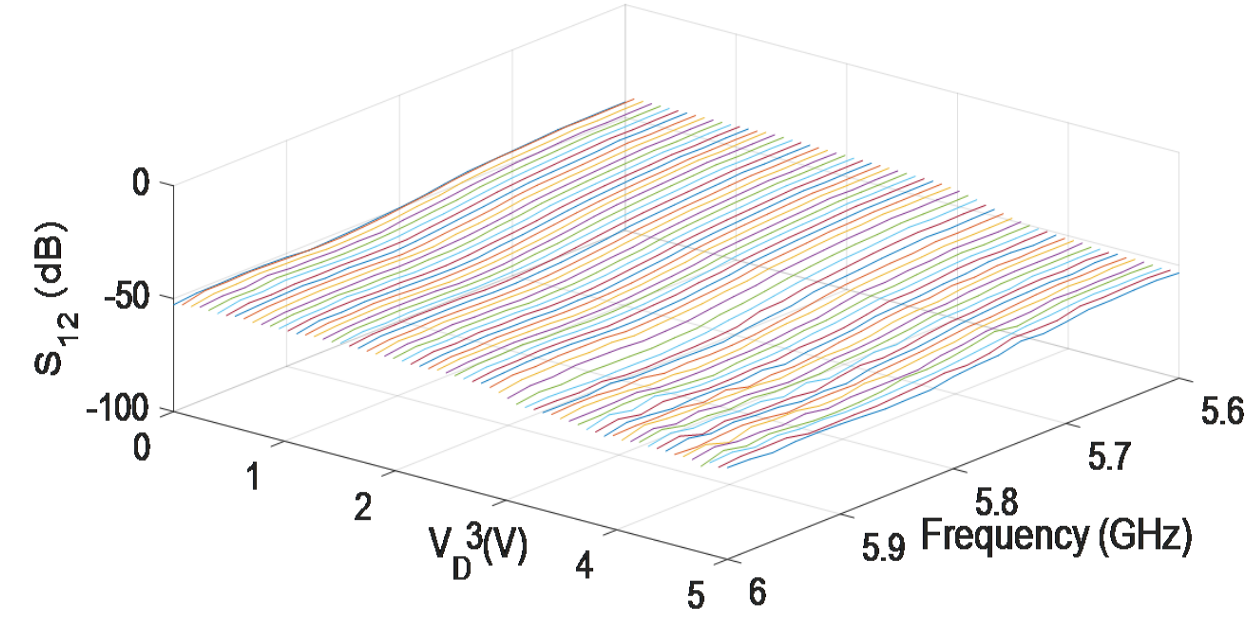

(d)

Figure 7. 3D Graphs of $S_{21}, S_{11}, S_{22}, S_{12}$ versus $5.7 \mathrm{GHz}-5.9 \mathrm{GHz}$ frequency interval and $0 \mathrm{~V}-5 \mathrm{~V} V_{D}$ voltage interval (a) 3D Graph of $S_{21}$ versus frequency and $V_{D}$ (b) 3D Graph of $S_{11}$ versus frequency and $V_{D}(c) 3 D$ Graph of $S_{22}$ versus frequency and $V_{D}(d) 3 D$ Graph of $S_{12}$ versus frequency and $V_{D}$

Table 2. PA performance parameters comparison for $\mathrm{V}_{\mathrm{D}}$ at $3.095 \mathrm{~V}$ and $5 \mathrm{~V} @ 5.8 \mathrm{GHz}$

\begin{tabular}{lccc} 
& $\mathrm{V}_{\mathrm{D}} @ 3.095 \mathrm{~V}$ & $\mathrm{~V}_{\mathrm{D}} @ 5 \mathrm{~V}$ & increase / decrease \\
\hline $\mathrm{S}_{21}(\mathrm{~dB})$ & 16.49 & 18.35 & 1.86 \\
$\mathrm{~S}_{11}(\mathrm{~dB})$ & -7.943 & -12.36 & -4.417 \\
$\mathrm{~S}_{22}(\mathrm{~dB})$ & -6.344 & -12.87 & -6.526 \\
$\mathrm{~S}_{12}(\mathrm{~dB})$ & -36.02 & -58.4 & -22.38 \\
$\mathrm{P}_{\text {dissipated }}$ & 0.07025 & 0.346 & 0.27575 \\
\hline
\end{tabular}

\section{CONCLUSION}

In the study, first, the S-parameters were measured at nominal $\mathrm{V}_{\mathrm{D}}$ with $200 \mathrm{MHz}$ bandwidths from $5.7 \mathrm{GHz}$ to $5.9 \mathrm{GHz}$ to show that the SBB5089Z is suitable for further analysis. Then, the variation of the linear performance parameters of the module was investigated with respect to changing DC biasing conditions. It has shown that increasing DC voltage levels increases gain $\left(S_{21}\right)$, but decreases input and output reflection coefficients $\left(S_{11}\right.$ and $\mathrm{S}_{22}$ ), and the reverse transmission coefficient $\left(S_{12}\right) . S_{21}$ increased by about $2 \mathrm{~dB}, \mathrm{~S}_{11}$ and $\mathrm{S}_{22}$ decreased by about $5 \mathrm{~dB}$ and $\mathrm{S}_{12}$ dropped by 22 $\mathrm{dB}$, when $\mathrm{V}_{\mathrm{D}}$ of the SBB5089Z were increased from $3.095 \mathrm{~V}$ to $5 \mathrm{~V}$. Increasing $\mathrm{V}_{\mathrm{D}}$ from $3 \mathrm{~V}$ to
$5 \mathrm{~V}$ increased power dissipation by about $0.275 \mathrm{~W}$. In relation to the altered DC conditions, all S-parameters of the SBB5089Z improved. It is clear that linear performance of the PA got better with increased DC voltage levels. Only power dissipation degraded because of increased current and voltage levels.

According to the results obtained in this study and according to the results of the change of the different performance parameters of the PA according to changing DC conditions, an adaptive DC biasing circuit will be designed. Therefore, the data obtained in this study are essential for adaptive PA design. As well as Sparameters for PA is important, DC power 
consumption is also very important in terms of thermal effects which occur in PA. In the study, it is obtained that there is a trade-off between $\mathrm{S}$ parameters and DC power consumption according to the increased DC conditions. It is also concluded that PA S-parameters can be used in supply voltage values less than $5 \mathrm{~V}$ in case of satisfying the desired conditions, thus reducing PA DC power consumption.

\section{REFERENCES}

Akbarpour M, Ghannouchi FM, Helaoui M, 2017. Current-Biasing of Power-Amplifier Transistors and Its Application for Ultra-Wideband High Efficiency at Power Back-Off. IEEE Transactions on Microwave Theory and Techniques 65 (4): 1257-1271.

Auer F, Schiller S, Kamper M, 2016. Linearity and efficiency improvement using envelope tracking power amplifier. German Microwave Conference (GeMiC), 14-16 March 2016, pp: 88-91.

Brinkhoff J, Parker AE, Leung M, 2003. Baseband impedance and linearization of FET circuits IEEE Transactions on Microwave Theory and Techniques, 51 (12): 2523-2530

Chen C-Q, Hao, M.-L., Li, Z.-Q., Du, Z. and Yang H., 2016. A $1.8-2.8 \mathrm{GHz}$ highly linear broadband power amplifier for LTE-A application. Progress In Electromagnetics Research C, 66:47-54.

Cohen N, Whitney J, Ryan D, Reece M. An adaptive power amplifier and control subsytem for use in space-based software defined radio applications. Asilomar Conference on Signals, Systems and Computers, 3-6 Nov. 2013,pp: 489-491.

Kaya A, Coskun Ö, Ardıç S. B., 2008. 2.4 GHz (WLAN) İçin A-Sınıfı Güç YükselticiTasarımı. Endüstri \& Otomasyon Elektrik,Elektronik, Makina, Bilgisayar ve Kontrol Sistemleri Dergisi, 139: 22-25.

Cripps S, C, 2002. Advanced Techniques in RF Power Amplifier Design. Artech House, pp:1-31, Boston, London.

Gecan D, Gjertsen KM, Olavsbråten M, 2017. Novel Metric Describing Total Nonlinearity of Power Amplifier With a Corresponding Figure of Merit for Linearity Evaluation and Optimization. IEEE Microwave and Wireless Components Letters 27 (1): 85-87.

Gecan D, Olavsbråten M, Gjertsen KM, 2016. Measured linearity improvement of $10 \mathrm{~W}$ GaN HEMT PA with dynamic gate biasing technique for flat transfer phase. IEEE MTT-S International Microwave Symposium (IMS), 22-27 May 2016 2016, pp 1-4.
Harzheim T, Heuermann H, Marso M, 2016. An adaptive biasing method for SRD comb generators. German Microwave Conference (GeMiC), 14-16 March 2016, pp 289-292.

Jing Y, Bakkaloglu B, 2017. A High Slew-Rate Adaptive Biasing Hybrid Envelope Tracking Supply Modulator for LTE Applications. IEEE Transactions on Microwave Theory and Techniques 65 (9): 3245-3256.

Lee H, Kwon J, Lim W, Lee W, Kang H, Hwang K. C, Lee K. Y, Park C. S, Yang Y, 2017. Optimized Current of the Peaking Amplifier for Two-Stage Doherty Power Amplifier. IEEE Transactions on Microwave Theory and Techniques 65 (1): 209217.

Lee M. W, Kam S. H, Lee Y. S, Jeong, Y. H, 2010. A Highly Efficient Three-Stage Doherty Power Amplifier with Flat Gain for WCDMA Applications. Journal of Electromagnetic Waves and Applications. 24 (17-18): 2537-2545.

Olavsbråten M, Gecan D, 2017. Bandwidth Reduction for Supply Modulated RF PAs Using Power Envelope Tracking. IEEE Microwave and Wireless Components Letters. 27 (4): 374-376.

Pedro J, C, and Carvalho N, B, 2003. Intermodulation Distortion in Microwave and Wireless Circuits, Artech House, pp: 312-315, Boston, London.

Pozar, D, 2012. Microwave Engineering. Third Edition, Wiley, pp:600, United States of America.

Saad P, 2006. Design a Highly Linear Power Amplifier Based on HBT. Master's Thesis, Electronics/Telecommunication, 80, Gävle., University of Gävle Department of Technology.

Şenel, B., M. Kahriman, Şenel F. A, 2017. Besleme ve RF Giriş Gücü Şartlarının WiMax Güç Yükselteci Performans Parametrelerine Olan Etkisinin İncelenmesi. Süleyman Demirel Üniversitesi Mühendislik Bilimleri ve Tasarım Dergisi 5 (3).

Tafuri FF, Sira D, Jensen OK, Larsen T, 2013. Efficiency enhancement of an envelope tracking power amplifier combining supply shaping and dynamic biasing. European Microwave Conference, 6-10 Oct. 2013, pp:1491-1494.

Tripathi G. C, Rawat M, Kamath S, Kartikeyan M. V, 2017. Linearization of traveling-wave tube amplifiers using digitally supported signal injection technique. Journal of Electromagnetic Waves and Applications, 31 (17): 1802-1815.

Wong S. K, Ooi, C. P, Pang W. L, Chan, K. Y, 2012. A High Gain and High Efficiency Cmos Driver Amplifier for $3.5 \mathrm{Ghz}$ WiMAX Applications. Journal of Electromagnetic Waves and Applications, 26 (4): 512-524. 